\title{
EFEKTIFITAS MATHMAGIC DALAM PENINGKATAN HASIL BELAJAR MATEMATIKA
}

\author{
ARI IRAWAN \\ mascan_89@yahoo.com \\ 085691331979 \\ CHATARINA FEBRIYANTI \\ chatarina022@gmail.com \\ 081398585296
}

Program Studi Teknik Informatika, FTMIPA Universitas Indraprasta PGRI

\begin{abstract}
Abstrak. Penelitian ini bertujuan untuk mengetahui tentang efektifitas penggunaan mathmagic terhadap hasil belajar matematika peserta didik tingkat sekolah dasar. Metode yang digunakan dalam penelitian ini adalah metode eksperimen yaitu dengan memberikan treatmen atau perlakuan pada sampel penelitian. Dimana akan membandingkan antara pretes dan postes. Pengujian hipotesis penelitian dengan cara uji t yaitu uji dua beda rata-rata. Setelah dilakukan penelitian didapatkan hasil 0,012<0,05 maka dapat disimpulkan terdapat perbedaan rata-rata antara sebelum dan sesudah treatmen. Dengan nilai korelasi sebesar 0,494 yang berarti cukup kuat atau koefisien determinasi $24,41 \%$. Dengan nilai efektifitas jika dibandingkan antara sebelum dan sesudah treatmen sebesar $90,42 \%$.
\end{abstract}

Kata kunci: Efektifitas, Mathmagic, Hasil Belajar Matematika, Sekolah Dasar

\begin{abstract}
This study aims to determine the effectiveness of the use of mathmagic on learning outcomes of mathematics at elementary school. The method used in this study is the experimental method is to provide treatments or treatment in the study sample. Where will compare between pretest and posttest. Research hypothesis testing by means of the $t$ test are two different test average. After a study found 0,012 results $<0.05$ it can be concluded there is an average difference between before and after treatments. With the correlation value of 0.494 , which means strong enough or the coefficient of determination $24.41 \%$. With the value of effectiveness when compared between before and after treatments amounted to $90.42 \%$.
\end{abstract}

Keywords: Effectiveness, Mathmagic, Results Learning Mathematics, Elementary School

\section{PENDAHULUAN}

Dalam upaya peningkatan keberhasilan pendidikan diperlukan adanya inovasi dalam proses pembelajaran, oleh karena itu guru harus memiliki daya kreatifitas yang tinggi sehingga pembelajaran yang dilakukan menjadi lebih efektif dan efisien. Pendidikan yang terjadi pada tingkat sekolah dasar menjadi sangat penting karena pada usia tingkat sekolah dasar inilah terjadi pemahan konsep-konsep dasar matematika yang harus siswa ketahui untuk bekalnya kelak ditingkat pendidikan selanjutnya.

Pendidikan pada dasarnya diselenggarakan dalam rangka membebaskan manusia dari berbagai persoalan hidup yang melingkupinya. Menurut Freire (Yunus, 2005: 1) menyatakan pendidikan merupakan salah satu upaya untuk mengembalikan fungsi manusia menjadi manusia agar terhindar dari berbagai bentuk penindasan, kebodohan 
sampai kepada ketertinggalan. Pendidikan pada hakikatnya merupakan suatu transfer pengetahuan dari semua bentuk kejadian di dunia dari makhluk hidup yang satu ke makhluk hidup yang lainnya, dan nantinya akan mempengaruhi proses kehidupan makhluk hidup itu sendiri. Pendidikan adalah kebutuhan dasar (basic need) hidup manusia. Pendidikan juga merupakan sebagai hak asasi manusia, dalam arti yang lebih luas bahwa pendidikan bertujuan untuk memberikan kemerdekaan kepada manusia dalam mempertahankan hidupnya. Di dalam prosesnya pendidikan selalu mengalami perubahan selaras dengan proses pertumbuhan suatu masyarakat. Setiap masyarakat mempunyai cara tersendiri antara satu dengan yang lainnya sesuai dengan pemahaman, pengertian, dan tujuan hidup yang mereka hayati. Sistem pendidikan biasanya berbentuk sesuai dengan pandangan hidup suatu masyarakat. Apabila pandangan hidup suatu masyarakat terbuka, maka akan lebih mudah untuk menyesuaikan diri dengan tuntutan zaman, dan dalam sistem pendidikannya pun akan banyak memberikan kesempatan kepada generasi baru untuk mengembangkan dan mempersiapkan diri guna menghadapi tuntutan zaman yang selalu berubah.

Perubahan-perubahan dalam dunia pendidikan biasanya diikuti oleh kemajuan ilmu pengetahuan dan teknologi, karena kemajuan tersebut tentu saja harus didukung oleh setiap pelaku pendidikan agar pendidikan dapat diselaraskan sesuai dengan kebutuhan dan perkembangan zaman. Untuk itu, guru selaku pelaku pendidikan harus memberikan wawasan kepada anak didiknya agar turut serta membangun iklim pendidikan. Dalam peranannya pelaku pendidikan mengarahkan kepada anak didiknya untuk berfikir kretif dan inovatif serta menarik. Pemikiran yang demikian itu tidak datang dengan sendirinya melainkan harus melalui rangsangan metode pembelajaran yang variatif serta menarik minat anak didik.

Sejalan dengan tujuan pendidikan nasional dan tujuan dari mata pelajaran matematika, maka berbagai macam cara ditempuh oleh pelaku pendidikan maupun orang yang perduli terhadap pendidikan baik yang bersifat formal maupun non formal untuk terus menciptakan metode pembelajaran yang kreatif, inovatif serta menarik minat anak didik untuk selalu mencintai dan menyukai terhadap belajar matematika, sebab belajar matematika menurut sebagian besar anak-anak merupakan pembelajaran yang sangat sulit dan memusingkan. Banyak metode pembelajaran yang berkembang dewasa ini yang telah diciptakan untuk memudahkan anak didik untuk menyukai terhadap matematika diantaranya adalah metode belajar mathmagic.

Metode belajar mathmagic adalah salah satu metode belajar terhadap operasi hitung pada pelajaran matematika yang diantaranya adalah operasi hitung perkalian. Dalam metode mathmagic anak didik diarahkan untuk dapat memahami operasi hitung perkalian dengan cara cepat dan mudah. Metode mathmagic ini nantinya tidak hanya diaplikasikan diatas kertas namun diharapkan anak didik mampu menghitung perkalian menggunakan daya nalarnya (operasi hitung tanpa melalui penulisan terlebih dahulu).

Akan tetapi, dalam kegiatan pembelajaran sebelum mengenal lebih jauh tentang perkalian sebaiknya guru mengetahui terlebih dahulu kemampuan anak didiknya. Sebab, pada perkalian ini anak didik minimal haruslah paham tentang dasar matematika yaitu penjumlahan dan pengurangan, sebab arti dari perkalian adalah penjumlahan berulang. Setelah paham betul kemampuan anak didik tentang penjumlahan dan pengurangan, barulah guru dapat menerapkan perkalian. Sesuai dengan uraian diatas, maka kami mencoba menerapkan metode mathmagic dengan maksud supaya setiap individu pelajar memiliki kemampuan operasi hitung perkalian yang mudah dan cepat serta mampu menghitung operasi hitung perkalian dengan menggunakan daya nalar. Oleh sebab itulah penelitian ini mengambil judul efektifitas mathmagic terhadap hasil belajar matematika pada siswa sekolah dasar di Kabupaten Bogor. 


\section{TINJAUAN PUSTAKA}

\section{Hasil Belajar Matematika}

Undang-undang Republik Indonesia No. 20 Tahun 2003 tentang Sistem Pendidikan Nasional Pasal 1 disebutkan bahwa "belajar adalah proses interaksi peserta didik dengan pendidik dan sumber belajar pada suatu lingkungan belajar". Sedangkan sumber belajar berperan dalam menyediakan berbagai informasi dan pengetahuan yang diperlukan dalam mengembangkan berbagai kompetensi yang diinginkan pada bidang studi atau mata pelajaran yang dipejarainya. Oleh karena itulah sumber belajar menjadi hal yang penting dalam memberikan hal yang positif dan penjamin peningkatan mutu pendidikan tersebut.

Mulyati (2005: 5) menyatakan bahwa belajar merupakan suatu usaha sadar individu untuk mencapai tujuan peningkatan diri atau perubahan diri melalui latihanlatihan dan pengulangan-pengulan, perubahan yang terjadi bukan karena peristiwa kebetulan. Dari definisi tersebut dapat disimpulkan bahwa belajar merupakan suatu proses latihan secara terus menerus dan berkesinambungan sehinga menghasiakn suatu perubahan kearah yang lebih baik.

Irawan (2015: 183) menyatakan bahwa belajar merupakan suatu proses pembelajaran yang akan memperteguh kelakuan dan pengalaman-pengalaman dalam kehidupannya bahwa proses pembelajaran nantinya akan merubah tingkah laku dari si pembelajar itu sendiri. Dari pengertian diatas maka disimpulkan bahwa belajar merupakan suatu proses pengalaman dalam upaya merubah tingkah laku.

Undang-Undang No 20 Tahun 2003 Bab XVI pasal 58 menyatakan bahwa evalusi hasil belajar peserta didik dilakukan oleh pendidik untuk memantau proses, kemajuan, dan perbaikan hasil belajar peserta didik secara berkesinambungan. Dari pengertian diatas maka hasil belajar matematika adalah suatu proses evaluasi yang dilakukan secara kontinu ke arah yang lebih baik.

Asmarani (2013: 68) menayatakan bahwa hasil belajar bisa diartikan sebagai hasil yang diperoleh karena adanya aktifitas belajar yang telah dilakukan. Dari pengertian tersebut dapat disimpulkan bahwa hasil belajar merupakan hasil setelah seseorang melakukan proses pembelajaran.

Soejadi dalam Asmarani (2013: 67) mengemukakan bahwa beberapa definisi atau pengertian tentang matematika berdasarkan sudut pandang pembuatnya sebagai berikut:

1) Matematika adalah cabang ilmu pengetahuan eksak dan terorganisasi secara sistematik,

2) Matematika adalah pengetahuan tentang bilangan dan kalkulasi, 3) Matematika adalah pengetahuan tenatang penalaran logik dan berhubungan dengan bilangan, 4) Matematika adalah pengetahuan tentang fakta-fakta kuantitatif dan masalah tentang ruang dan bentuk, 5) Matematika adalah pengetahuan tentang struktur-struktur yang logis, dan 6) Matematika adalah pengetahuan tentang aturan-aturan yang ketat.

Suriasumantri (Leonard, 2005: 64) mengemukakan bahwa matematika mempunyai kelebihan lain dibandingkan dengan bahasa verbal. Matematika mengembangkan bahasa numerik yang memungkinkan kita melakukan pengukuran secara kuantitaif. Dari pengertian tersebut maka jelaslah matematika memiliki ciri khusus yang dapat diterjemahkan kedalam bahasa verbal bagitupun sebaliknya bahasa verbal dapat ditulis dalam bentuk matematik.

Dari pengertian-pengertian diatas maka dapat disimpulkan hasil belajar matematika adalah suatu proses penilaian secara keseluruhan dan kontinu setelah peserta didik mengalami pengalaman pembelajaran. 


\section{Mathmagic}

Metode mathmagic adalah metode pembelajaran matematika yang menitikberatkan pada pemahaman anak akan konsep dasar matematika yang benar. Pembelajaran mathmagic menggunakan berbagai macam permainan sehingga menjadi suatu pengalaman yang menyenangkan bagi anak. Pembelajaran yang dilakukan dengan hati yang riang gembira akan meninggalkan kesan yang mendalam sehingga anak akan lebih mudah memahami pelajaran yang diberikan.

Dalam proses pembelajarannya, metode mathmagic akan meningkatkan rasa percaya diri anak, sehingga mereka akan mampu dan berani untuk mengerjakan soal dan mencoba untuk menyelesaikannya. Metode mathmagic mengajarkan metode aljabar, konsep berhitung dasar seperti penambahan, pengurangan, perkalian, pembagian, pangkat, akar dan pecahan, dengan memperhatikan aspek psikologis anak. Hal ini sesuai pernyataan Setyono (2007: 8) menyatakan bahwa mathmagic adalah suatu pendekatan dan cara pandang baru terhadap matematika, terutama dalam cara menyampaikan materi. Materi disajikan dengan cara yang gembira, konkret dan memperhatikan aspek-aspek psikologis, cara kerja otak, gaya belajar, dan kepribadian anak didik. Dengan mathmagic pengerjaan hitungan dasar akan menjadi jauh lebih mudah dan sederhana sehingga akan tertanam suatu kesan awal bahwa matematika itu mudah dan menyenangkan.

Metode mathmagic diperuntukkan bagi anak-anak yang sudah mengenal berhitung (katakan dengan metode Konvensional) dan penjumlahan hingga perkalian, tidak bagi anak yang masih dalam proses mengenal bilangan atau Matematika.

Handojo (2007) menyatakan bahwa "Metode mathmagic tidak hanya menyenangkan, tetapi juga mudah dipelajari. Metode mathmagic lebih dari sekedar teknik perhitungan cepat. Anak-anak dapat mengembangkan strategi untuk penyelesaian soal secara umum. Jika anak-anak tidak tahu atau tidak pernah belajar bagaimana cara menyelesaikan soal maka anak-anak akan menyusun metode sendiri."

Dalam metode mathmagic tidak semata-mata diutamkan kecepatan, namun juga kebenaran dan logika jawaban yang dihasilkan. Secara prinsip dalam metode mathmagic, setiap persoalan perhitungan $(+,-, \mathrm{x},:$ ) dikerjakan dengan strategi yang sesuai untuk mendapatkan jawaban yang sederhana, mudah, cepat dan tepat. Jadi seseorang harus kreatif dan dalam menentukan strategi berhitung sesuai dengan soal yang dihadapi. Tidak diperlukan alat bantu apapun kecuali alat tulis menulis, itupun jika diperlukan, dan starategi yang tepat. Rasa percaya diri sang anak akan bertambah setelah sang anak mengetahui cara penggunaannya sehingga akan meningkatkan hasil belajar anak.

Kelebihan Belajar Mathmagic: 1) Tidak diperlukan alat bantu apapun, kecuali alat tulis menulis, itupun jika diperlukan, dan strategi yang tepat, 2) Dapat digunakan oleh siapa saja, baik anak yang tidak suka (tidak berbakat) maupun yang suka (berbakat) matematika, dan 3) Rasa percaya diri sang anak akan bertambah setelah sang anak mengetahui cara penggunaanya sehingga akan berkorelasi positif terhadap pelajaran matematika di sekolahnya. Bahkan berkorelasi positif juga untuk mata pelajaran lain.

Dari uraian diatas tampak kelebihan-kelebihan dari metode Mathmagic, namun, kekurangan metode mathmagic juga ada. Seperti yang diungkapkan oleh Ediati (2008): “ Kekurangan metode Mathmagic adalah banyaknya strategi yang harus diketahui. Sebagaimana aslinya dalam Ganita Sutra, hanya ada 16 Sutra (Rumus besar) dan sutra itu masih bisa dipecah-pecah lagi menjadi beberapa sutra kecil. Bagi anak atau orang tua yang tidak sabar, mungkin hal ini dianggap sebagai "harus menghapal banyak rumus". Tetapi jika diperhatikan lebih teliti, hal ini tidak terjadi........"

Jadi tampak bahwa dalam metode mathmagic sang anak harus tahu banyak strategi. Hal ini membutuhkan waktu untuk memahami mathmagic. Serta tujuan terpenting adalah bukan bisa berhitung cepat semata-mata, tetapi harus lebih dari itu, 
yaitu agar anak menikmati dan mencintai matematika untuk menjawab persoalan hidupnya sendiri sehari-hari.

Dalam metode Mathmagic terdapat 5 kunci metal matematika dalam perkalian, yaitu:

1) Pahami arti angka

Satu cara untuk mengingat perkalian dalam kepala kita adalah dengan mendapatkan gambaran yang jelas mesing-masing posisi digit. Apakah satuan, puluhan, ratusan atau ribuan. Jika kita dapat menggambarkan konsep ini dan menyimpan

2) Dalam memori kepala kita

Kita dapat mengerjakan soal-soal yang lebih rumit. Pikirkan angka maju daripada mundur. Metode perhitungan dari kiri ke kanan sangat penting dan mudah dilakukan. Hal ini karena kita dapat segera menyimpulkan perkiraan jawaban.

3) Kembangkan memori kita

Perhitungan perkalian dengan metode dari kiri ke kanan lebih cepat dan mudah menciptakan gambaran dalam otak kita daripada perkalian dengan metode lama. Jika melatih diri mengikuti angka dasar dalam kepala kita akan menemukan bahwa kita tidak memerlukan pensil untuk mengalikan atau menambah.

4) Latihan

Perkalian silang adalah trik ringan sampai kita mendapatkan teknik dan strategi yang ampuh. Catat dalam ingatan "latihan akan mengembangkan kemampuan dan keterampilan kita."

5) Kreatif

Perkalian selalu penuh dengan kemungkinan. Jadi kita harus lebih kreatif dalam menentukan strategi apa yang akan digunakan. Ingat, perkalian angka akan sering kita temui, dimana saja, dan kapan saja.

Dari pengertian-pengertian diatas maka dapat disimpulkan bahwa mathmagic merupakan suatu terobosan belajar yang menyenangkan bagi peserta didik dalam memperlajarari dan menggunakan rumus-rumus matematika. Sehingga mathmagic dapat diaplikasikan dengan mudah dipahami oleh peserta didik dan dilakukan oleh guru maka dari itulah penggunaan mathmagic dapat memupuk rasa percaya diri peserta didik dalam menaklukan pertanyaan-pertanyaan mata pelajaran matematika.

\section{METODE}

Penelitian ini dilaksanakan di tiga sekolah yang berada di Kecamatan Cileungsi Kabupaten Bogor yaitu SDN 01, SDN 05 dan SDN 09 Cileungsi. Pelaksanaan dalam waktu lima bulan mulai dari Maret 2015 sampai dengan Juli 2015.

Metode yang digunakan dalam penelitian ini adalah metode eksperimen dengan teknik komparasi serta menghitung nilai efektifitasnya. Populasi dalam penelitian ini adalah siswa-siswi SDN 01, 05 dan 09 Cileungsi Kabupaten Bogor. Sampel diambil dari populasi terjangkau dengan teknik multistage random sampling secara bertahap. Dimana diambil masing-masisng 30 siswa-siswi dari masing-masing sekolah yang dijadikan sebagai kelas eksperimen. Sehingga total sampel pada penelitian ini sebanyak 90 orang.

Pada masing-masing kelas eksperimen diberikan treatmen berupa pembelajaran mathmagic. Namun sebelum diberikan treatmen terlebih dahulu diberikan pretest untuk mengukur sampai sejauh mana kemampuan awal siswa sebelum diberikan treatmen dan setelah treatmen akan diberikan postes. Dimana instrumen tes tersebut telah diuji coba dan divalidasi terlebih dahulu. 


\section{HASIL DAN PEMBAHASAN}

Hasil pengukuran yang dilakukan terhadap 90 responden yang menjadi objek penelitiam dihasilkan data sebagai berikut:

Tabel 1. Perbandingan nilai pretes dan postes

\begin{tabular}{lcc}
\hline Nilai & Pretes & Postes \\
\hline Mean & 65,5 & 72,44 \\
Median & 70 & 80 \\
Modus & 90 & 85 \\
Standar Deviasi & 25,81 & 24,62 \\
\hline
\end{tabular}

Dari hasil pengujian normalitas dengan menggunakan uji Kolomogorov-Smirnov untuk semua sampel lebih besar dari 0,05 yaitu sebesar 0,102 untuk nilai pretes dan 0,236 untuk nilai postes. Dengan demikian bahwa data dari semua sampel penelitian antara sebelum dan sesudah treatmen pada penelitian ini berdistribusi normal. Dari hasil pengujian homogenitas didapat 0,490 untuk semua sampel lebih besar dari 0,05. Dengan demikian bahwa sampel-sampel tersebut berasal dari populasi yang homogen.

Hasil perhitungan yang dilakukan untuk melihat sebaran siswa yang memikiki nilai diatas dan dibwah rata-rata pada nilai pretes dan postes terdapat pada tabel dibawah ini:

Tabel 2. Perbandingan jumlah siswa terhadap pretes dan postes.

\begin{tabular}{lc}
\hline & Jumlah Siswa \\
\hline Nilai Postes $<$ Nilai Pretes & 27 \\
Nilai Postes $>$ Nilai Pretes & 47 \\
Nilai Postes $=$ Nilai Pretes & 16 \\
\hline
\end{tabular}

Nilai korelasinya adalah 0,494 ini berarti terdapat hubungan yang cukup kuat dan positif. Dengan kontribusi sebesar $24,41 \%$ sisanya dipengaruhi oleh faktor lain sebesar 75,59\%. Berdasarkan hasil pengukuran dapat diketahui nilai Asym Sig adalah 0,012. Karena nilai signifikansi nya adalah $0,012<0,05$, maka dapat disimpulkan bahwa ada perbedaan nilai pretes dan postes. Dan ini berarti terdapat efektifitas penggunaan mathmagic terhadap hasil belajar matematika.

Saksono (1984) mengemukakan Efektifitas adalah seberapa besar tingkat kelekatan output yang dicapai dengan output yang diharapkan dari sejumlah input. Berdasarkan hal tersebut maka untuk menghitung nilai efektifitasnya adalah sebagai berikut:

$$
\begin{aligned}
& \text { Efektifitas }=\frac{\text { Rata }- \text { rata_sebelum_treatmen }}{\text { Rata }- \text { rata_setelah_treatmen }} \times 100 \% \\
& \text { Efektifitas }=\frac{65,50}{72,44} \times 100 \%=90,42 \%
\end{aligned}
$$

Jika dilihat dari perbandingan nilai rata-rata sebelum dan sesudah diberikan treatmen maka nilai efektifitasnya sebesar 90,42\%. Hal ini berarti pemberian mathmagic memiliki nilai efektifitas yang cukup tinggi.

Dari hasil peneltian diatas terihat bahwa penggunaan mathmagic dapat meningkatkan hasil belajar matematika peserta didik. Namun ada beberapa hal yang harus diperharikan sebelum menggunakan mathmagic pada peserta didik diharapkan 
peserta didik telah memiliki pengetahuan awal yang cukup. Hal ini penting karena jika tidak memiliki pengetahuan awal yang cukup akan membuat peserta didik akan semakin bingung dan tidak nyambung dengan apa yang diberikan oleh guru. selanjutnya karena ada banyak cara untuk menghapal sehingga peserta didik diharapkan dapat memahami hafalan berupa syarat dan ketentuan yang berlaku kapan dan bagaimana mathmagic dapat dilakukan dengan soal-soal tertentu. Hal inilah yang terkadang membuat bingung peserta didik.

Dalam prakteknya mathmagic banyak sekali menggunakan rumus-rumus khusus sehingga hal ini yang membuat mathmagic menjadi tidak disenangi oleh sebagian peserta didik. Maka dari itulah yang lebih sering paham tentang mathmagic adalah peserta didik yang memiliki penalaran yang cukup tinggi jika tidak memiliki daya nalar yang tinggi mathmagic akan semakin sulit untuk anak-anak biasa.

Dari hasil penelitian ini terlihat adanya peningkatan nilai rata-rata sebelum dan setelah diberikan treatmen mathmagic. Maka dalam hal ini efektifitas mathmagic untuk meningktakan hasil belajar matematika telah terbukti. Dalam pembelajaran yang dilakukan di tiga sekolah tersebut terlihat pada masing-masing sekolah ada perbedaan karakteristik siswa yang diajarnya. Terlihat pada sekolah SDN cileungsi 1 lebih unggul jika dibandingkan dengan SDN 09 dan 05. Hal ini dapat dirasakan pada kegiatan proses pembelajaran yang dilakukan oleh guru.

Syafik (2012: 23) mengemukakan bahwa pembelajaran matematika yang efektif diharapkan dapat mencapai tujuan kognitif, afektif dan psikomotor. Artinya dengan adanya pembelajaran dengan menggunakan mathmagic diharapkan tercapai hasil pembelajaran sesuai dengan ranah kognitif, afektif dan psikomotornya. Karena dalam pembelajaran mathmgic siswa menjadi lebih bergairah sehingga dapat meningkatkan minat dan rasa ingin tahu siswa yang cukup tinggi dengan pembelajaran baru ini. Karena pembelajaran perkalian yang dengan menggunakan metode ini jauh akan lebih cepat mendapatkan jawaban yang tepat terhadap soal-soal yang ditanyakan oleh guru.

Harini dan Nilakusumawati (2014: 112 ) menyatakan bahwa metode ringkas efektif dalam mengatasi kesulitan siswa dalam perkalian susun pelajaran matematika. Dari hal tersebut pada siswa sekolah dasar hendaknya dalam pemberian pembelajaran matematika dikelas tidak semata-mata hanya melihat pada aspek materi harus selesai akan tetapi perlu adanya strategi dan metode yang tepat dalam menyamakan antara bobot tingkat kesulitan materi dengan cara yang ringkas efektif dan efisen agar materi sampai kepada siswa dengan cepat tepat dan memenuhi sasaran tujuan pembelajaran.

Maka dari itu mathmagic dapat menjadi salah satu metode yang efektif dan efiesien dalam menjelaskan materi perkalian pada siswa kelas III sekolah dasar. Dengan melihat hasil pada masing-masing kelas eksperimen pada tiga sekolah dan membandingkan antara sebelum dan setelah mendapatkan treatmen ternyata terdapat perbedaan hasil belajar yang jauh lebih baik jika dibandingkan sebelum treatmen

\section{PENUTUP \\ Simpulan}

Hasil analisis dan pengujian hipotesis diatas menunjukan bahwa terdapat perbedaann antara sebelum dan sesudah diberikan treatmen. Dan mempunyai nilai efektifitas yang cukup tinggi. Dengan demikian mathmagic dapat menjadi salah satu solusi untuk memberikan kemudahan siswa dalam mempelajari matematika. 
Saran

Berdasarkan hasil penelitian ini maka saran dan harapan yang bisa peneliti sampaikan yaitu guru dapat lebih mengembangkan profesionalismenya dalam mengajar agar dapat memilih motode yang tepat untuk digunakan dalam proses pembelajaran sebagai upaya untuk meningkatkan pemahaman dan pengetahuan serta hasil belajar yang lebih maksimal lagi.

\section{Ucapan Terimakasih}

Kami selaku peneliti mengucapkan terimakasih kepada kepala sekolah SDN Cileungsi 1, Cileungsi 5 dan Cileungsi 9 serta guru kelas III pada masing-masing sekolah yang telah bekerjasama dalam penelitian ini. Selanjutnya kepada pihak Universitas Indraprasta yang telah membiayai penelitian ini melalui LPPM. Serta pihak-pihak yang telah banyak membantu suksesnya penelitian ini.

\section{DAFTAR PUSTAKA}

Asmarani, Aina. 2013. Peningkatan Aktifitas dan hasil belajar operasi pembagian dengan menggunakan media POPITCHING SIPP LAH pada siswa kelas III SDN Sidomulyo 03 Kota Batu. Jurnal Mimbar Pendidikan Indonesia, 1(1): 64-74

Irawan, Deni. Ari Irawan. 2014. Peran ai-learn terhadap hasil belajar matematika. Jurnal Formatif, 4(3): 181-187

Ediaty. 2008. Kelebihan dan Kekurangan Mathmagic. Jakarta: Mizan

Enik, Chaerul Umah. 2013. Peningkatan hasil belajar operasi hitung bilangan bulat melalui MTB pada siswa kelas IV SD Muhammadiyah 1 Sidoarjo. Jurnal Mimbar Pendidikan Indonesia, 1(2): 40-48

Handojo. 2007. Cara Pandang Baru Belajar Matematika. Bandung: Rosdakarya

Harini, L.P.I., Nilakusmawati, D.P.E., 2014. Kajian efektivitas penerapan metode ringkas dalam perkalian susun. Jurnal Matematika, 4 (2): 111 - 129

Leonard. 2013. Peran kemampuan berpikir kritis terhadap prestasi belajar matematika. Jurnal Mimbar Pendidikan Indonesia, 1(2): 61-71

Maman \& Sarjaya. 2014. Metode tutor sebaya untuk meningkatkan hasil belajar matematika pada materi pengolahan data. Jurnal Formatif, 4(1): 71-79

Mulyati. 2005. Peningkatan hasil belajar materi bangun ruang sisi datar melalui pemanfaatan media tekung dengan model kooperatif two stay to stray siswa kelas VIII SMPN 25 Surakarta. Jurnal Mimbar Pendidikan Indonesia, 1(2): $1-12$

Setyono. 2007. Matchmagic Untuk Pembelajaran Menyenangkan. Jakarta: Yudhistira

Syafik, Abu. 2012. Permainan matematika sebagai metode alternatif dalam pembelajaran matematika pada siswa kelas 1 sekolah dasar. Jurnal LIMITPendidikan Matematika. 1 (2): 21-36

Yunus. 2005. Tantangan Pendidikan Abad 21. Jakarta: Grafindo

Undang-Undang No 20 Tahun 2003 Tentang Sistem Pendidikan Nasional

http: //marthatanti.multiply.com/journal/item/6/ diakses tanggal 16 Maret 2015

http: //deparisiska.blogspot.com/2011/05/efektivitas-metode-mathmagic-dalam_16.html diakses tanggal 16 Maret 2015. 